\title{
CORRECTION
}

\section{Correction to: Do board characteristics affect bank performance? Evidence from the Eurozone}

\section{Ahmed Bouteska ${ }^{1}$ (i)}

Published online: 10 March 2021

(c) Springer Nature Limited 2021

\section{Correction to: \\ Journal of Asset Management (2020) 21:535-548 \\ https://doi.org/10.1057/s41260-020-00181-2}

After publication in Vol 21 Issue 6, it was noticed that we failed to include a reference. Therefore, we are publishing this erratum to update the reference list, to include the following:

Abdul Gafoor, C.P., V. Mariappan, and S. Thyagarajan. 2018. Board characteristics and bank performance in India. IIMB Management Review 30: 160-167.

Publisher's Note Springer Nature remains neutral with regard to jurisdictional claims in published maps and institutional affiliations.

The original article can be found online at https://doi.org/10.1057/ s41260-020-00181-2.

Ahmed Bouteska

ahmedcbouteska@gmail.com

1 Faculty of Economics and Management of Tunis, University of Tunis El Manar, Tunis, Tunisia 